\title{
ANALISIS PENGARUH PENYERAPAN KALOR TERHADAP EFISIENSI COOLING TOWER PADA TUNGKU INDUKSI PENGECORAN LOGAM DI POLMAN ASTRA
}

\author{
Komarudin $^{1}$, Rudi Saputra ${ }^{2}$, Satriyo Yudi Baskoro ${ }^{3}$ \\ Fakultas Teknologi Industri, Institut Sains dan Teknologi Nasional, Jakarta Selatan, Indonesia 123 \\ email $^{1}$ : komarudin.mt@gmail.com
}

\begin{abstract}
In the process of inducing metal, coil receives heat from the molten metal (molten). Therefore, it takes a cooling medium flowing in the coil casing and has a good conductivity. So here media of cooling tower water is used, so the water temperature can be maintained at the ambient air wet bulb temperature. With the optimal heat absorption cooling tower efficiency can be maintained. Besides, the material aluminum / molten can be melted well as the process of inducing metal running perfectly and there is no buildup of material on the walls of the furnace. With the application of a double pump with the series circuit to increase the water flow rate and can boost the absorption of the heat from the furnace wall and the pipe to the water coil.
\end{abstract}

Keywords: Efficiency cooling towers, improving heat absorption.

\section{PENDAHULUAN}

Cooling tower merupakan salah satu sistim pendingin yang mendinginkan media pendingin sampai bertemperatur mendekati temperature bola basah udara sekitar. Cooling tower ini bertujuan untuk mendinginkan coil elektroda pada furnace dan juga untuk pendinginan pada suhu ruangan panel listrik trafo dan kontrol unit. Terdapat dua point penting yang mempengaruhi proses peleburan terhadap kinerja cooling tower. Pertama, Tungku peleburan logam (furnace) terdapat coil sebagai penghantar listrik dan sangat membahayakan jika terjadi kebocoran karena retak atau pecah (berpotensi korsleting listrik). Kedua, pada VIP panel terdapat komponen listrik yang rentan terhadap panas akan mempengaruhi kinerja VIP panel menyebabkan alarm mesin.

Akibat dari pengaruh diatas maka mesin akan berhenti bekerja dan proses produksi terhenti, disamping itu akan mengakibatkan penumpukan material pada Dinding tungku akibat penurunan suhu material yang telah mencair dan akan retak bila menerima panas secara mendadak ketika menginduksi tungku.

\section{TINJAUAN PUSTAKA}

Dasar Proses Peleburan Logam Pada Tanur Induksi

Tungku induksi di polman astra menggunakan tipe tanur induksi coreless (tanpa inti), penampang tungku induksi terlihat pada gambar 1.

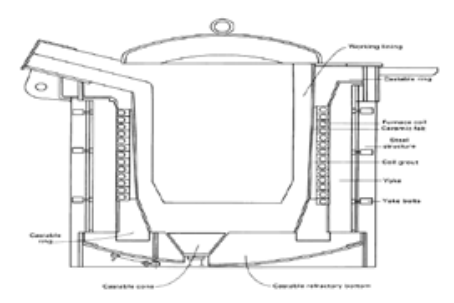

Gambar 1. Penampang tungku induksi coreless (Sumber : Metals HandBook VOL 15 - CASTING, 2004)

Prinsip kerja tungku induksi coreless adalah dengan menginduksi logam atau material alumunium dengan aliran arus listrik yang mengalir melalui kumparan coil yang mengelilingi dinding tungku induksi tersebut. Hal ini menyebabkan arus pengadukan secara elektromagnetik, ketika arus listrik masuk ke kumparan coil tembaga maka akan menghasilkan medan magnet, yang akan menginduksi material atau molten. Material akan menjadi panas dan akhirnya mencair. Jadi panas yang terjadi pada tungku induksi diperoleh dari radiasi panas molten. Gambar 2 menunjukkan pengadukan empat kuadran. Ini adalah pengadukan ini yang menghasilkan paduan yang sangat baik dan biaya murah dan membantu dalam memproduksi material yang bersifat kimia dan termalhomogen. 


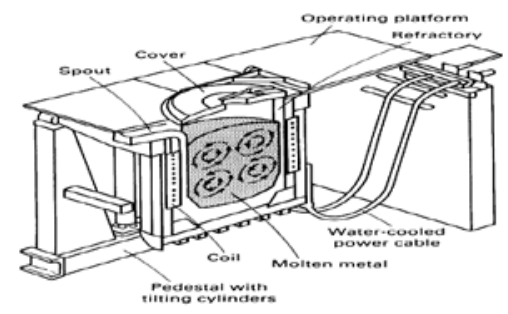

Gambar 2. Ilustrasi pengadukan dalam tungku (Sumber: Metals HandBook VOL 15 - CASTING, 2004)

\section{Definisi Cooling tower ${ }^{1}$}

Cooling tower merupakan suatu peralatan yang digunakan untuk menurunkan suhu aliran air dengan cara mengekstraksi panas dari air dan mengemisikannya ke atmosfir. menggunakan penguapan dimana sebagian air diuapkan ke aliran udara yang bergerak dan kemudian dibuang ke atmosfir. Sebagai akibatnya, air yang tersisa didinginkan secara signifikan. Menara pendingin mampu menurunkan suhu air lebih dari peralatanperalatan yang hanya menggunakan udara untuk membuang panas, seperti radiator dalam mobil, oleh karena itu biayanya lebih efektif dan efisien energinya. Proses tersebut ditunjukan pada gambar 3.

\section{Pengkajian Terhadap Menara Pendingin}

Kinerja menara pendingin dievaluasi untuk mengkaji tingkat approach dan range saat ini terhadap nilai desain, mengidentifikasi area terjadinya pemborosan energi dan memberikan saran perbaikan. Selama evaluasi kinerja, peralatan pemantauan yang portable digunakan untuk mengukur parameter-parameter yang terkait.

Parameter terukur tersebut kemudian digunakan untuk menentukan kinerja menara pendingin dengan beberapa cara. Yaitu:

1. Range,

Range CT $\left({ }^{\circ} \mathrm{C}\right)=\left[\right.$ suhu masuk CW $\left({ }^{\circ} \mathrm{C}\right)-$ suhu keluar CW $\left.\left({ }^{\circ} \mathrm{C}\right)\right]$

2. Approach,

Approach CT $\left({ }^{\circ} \mathrm{C}\right)=$ ssuhu keluar CW $\left({ }^{\circ} \mathrm{C}\right)-$ suhu wet bulb $\left.\left({ }^{\circ} \mathrm{C}\right)\right]$

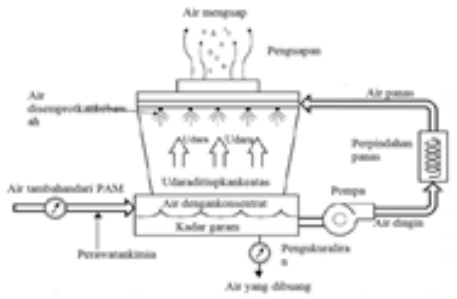

Gambar 3. Diagram skematik sistim

(Sumber: Laboratorium Nasional Pacific Northwest, 2001)

\footnotetext{
Energy Efficiency Guide for Industry in Asia -

www.energyefficiencyasia.org $\subseteq U N E P$
}

3. Efektivitas.

Efektivitas CT (\%) = $100 \times$ (suhu CW -suhu keluar CW) / (suhu masuk CW -suhu WB)

4. Kehilangan penguapan. (Perry):

Kehilangan penguapan $\left(\mathrm{m}^{3} / \mathrm{jam}\right)=0,00085 \times 1,8$ $\mathrm{x}$ laju sirkulasi $\left(\mathrm{m}^{3} / \mathrm{jam}\right) \mathrm{x}(\mathrm{T} 1-\mathrm{T} 2)$,

$\mathrm{T} 1-\mathrm{T} 2$ = perbedaan suhu antara air masuk dan keluar

5. Siklus konsentrasi (C.O.C). Merupakan perbandingan padatan terlarut dalam air sirkulasi terhadap padatan terlarut dalam air make up.

6. Kehilangan (Blow down),

Blow down = Kehilangan penguapan/ (C.O.C. 1)

7. Perbandingan Cairan dan Gas (L/G). L(T1 - T2)

$=\mathrm{G}(\mathrm{h} 2-\mathrm{h} 1)$

$L / G=(h 2-h 1) /(T 1-T 2)$

Dimana:

$\mathrm{L} / \mathrm{G}=$ perbandingan aliran massa cair terhadap gas $(\mathrm{kg} / \mathrm{kg})$

$\mathrm{T} 1=$ suhu air panas $\left({ }^{\circ} \mathrm{C}\right)$

$\mathrm{T} 2=$ suhu air dingin $\left({ }^{\circ} \mathrm{C}\right)$

h2 = entalpi uap campuran udara-air pada suhu wet-bulb keluar $\left({ }^{\circ} \mathrm{C}\right)$

h1 = entalpi uap campuran udara-air pada suhu wet-bulb masuk $\left({ }^{\circ} \mathrm{C}\right)$

\section{Perpindahan Panas Pada Cooling tower}

Pada setiap perbedaan temperatur didalam suatu benda atau antara benda yang lain selalu mengalami perpindahan panas sampai pada kesetimbangan temperatur tertentu. Perpindahan energi dari bagian suhu tinggi kebagian suhu rendah dapat terjadi secara konduksi, konveksi atau radiasi. Dalam kenyataan perpindahan panas dapat terjadi secara gabungan dari ketiga cara tersebut.

Berdasarkan karakteristik dan prinsip kerja cooling tower dalam penelitian studi kasus ini, perpindahan panas terjadi secara konduksi dan konveksi paksa.

\section{Perpindahan Panas Konduksi ${ }^{2}$}

Konduksi adalah perpindahan panas yang disebabkan oleh kontak langsung dari molekulmolekul benda padat dan pada permukaan tipis dari fluida cair atau gas ke molekul yang terdekat menyebabkan getaran yang memberikan energi kinetik molekul dan selanjutnya dirubah menjadi energi panas. Jika pada suatu benda terdapat gradien suhu (temperatur gradient) maka akan terjadi perpindahan energi dari bagian suhu tinggi kebagian suhu rendah. kita katakan bahwa energi berpindah secara konduksi atau hantaran dan bahwa laju perpindahan panas itu berbanding dengan gradient suhu normal

$$
q / A \sim d T / d x
$$

\footnotetext{
${ }^{2}$ Perpindahan Panas Dasar,Komarudin, Ir.MT
} 
Jika dimasukkan konstanta proposionalitas,

$\mathrm{q}=-\mathrm{k} \cdot \mathrm{A} \cdot \mathrm{dT} / \mathrm{dx} ;$ Untuk Plat datar

$\mathrm{q}=-\mathrm{k} \cdot \mathrm{A} \cdot \mathrm{dT} / \mathrm{dr} \quad$; Untuk tabung atau silinder

Untuk plat datar, seperti yang terlihat pada gambar 5.

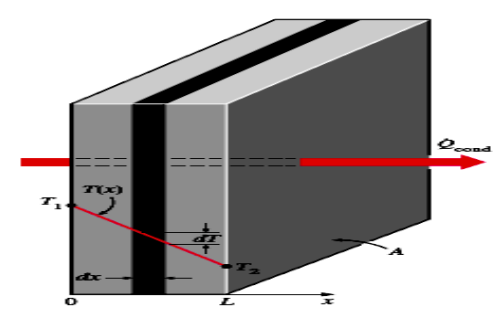

Gambar 5. Konduksi pada plat

(Sumber: Perpindahan Panas Dasar, Komarudin, hal 20)

$$
\begin{aligned}
& Q_{\text {cond }}=-k A \frac{d T}{d x} \quad Q_{\text {cond }}=\int_{x_{1}}^{x_{2}} d x=-k A \int_{T_{1}}^{T_{2}} d T \\
& Q_{\text {cond }}\left(x_{2}-x_{1}\right)=-k A\left(T_{2}-T_{1}\right) \\
& \mathrm{T}_{1}>\mathrm{T}_{2} \text { dan } \mathrm{x}_{2}-\mathrm{x}_{1}=\Delta x \text {, maka } \\
& Q_{\text {cond }}=\frac{-k A\left(T_{2}-T_{1}\right)}{x_{2}-x_{1}}=\frac{k A\left(T_{1}-T_{2}\right)}{\Delta x} \\
& Q_{\text {cond }}=\frac{k A\left(T_{1}-T_{2}\right)}{\Delta x}=\frac{\left(T_{1}-T_{2}\right)}{\frac{x}{k A}}=\frac{\left(T_{1}-T_{2}\right)}{R} \\
& R=\frac{x}{k A}=\quad \text { Tahanan Panas Konduksi }
\end{aligned}
$$

\section{Dimana :}

$Q \quad=$ Laju perpindahan kalor (J)

$k=$ Koefisien panas konduksi $(\mathrm{W} / \mathrm{m} . \mathrm{K})$

$A=$ Luas permukaan aliran panas (m2)

$T=$ Waktu (detik)

$\Delta \mathrm{T} \quad=$ Perbedaan temperatur $(\mathrm{K})$

$\Delta \mathrm{x} \quad=\operatorname{Jarak}(\mathrm{m})$

\section{Perpindahan Panas Konveksi}

Perpindahan panas konveksi adalah perpindahan panas yang terjadi pada fluida yang mengalir karena perbedaan massa jenis, yaitu fluida cair, gas ataupun udara. Perpindahan panas konveksi terbagi menjadi 2 (dua) golongan yaitu konveksi natural (alamiah) dan konveksi paksa.

\section{Konveksi Alami}

Konveksi alami, fluida bergerak dibawah pengaruh gaya-gaya apung yang muncul dari perubahan-perubahan densitas fluida. Karena dihasilkan oleh variasi densitas, aliran konvektif bebas merupakan aliran kompresibel, walaupun demikian jika perbedaan temperatur semakin kecil maka analisa terhadap kecepatan fluida (u), viskositas kinematik (v) dan temperatur ( $\mathrm{T}$ ) dapat dibuat dimana densitas (p) dianggap konstan.

\section{- Laju perpindahan panas konveksi}

Secara umum persamaan perpindahan panas konveksi adalah :

$q=\mathbf{h} \cdot \mathbf{A}\left(\mathbf{T}_{\mathbf{d}^{-}} \mathbf{T}_{\mathbf{f}}\right)$ (Watt)

dimana:

$\left(\mathrm{T}_{\mathrm{d}}-\mathrm{T}_{\mathrm{f}}\right)=\Delta \mathrm{T}=$ beda temperatur antara permukaan padat dan fluida, (C)

$\mathrm{h}=$ koeffisien perpindahan panas konveksi, Watt/(m2 C)

$\mathrm{A}=$ luas permukaan perpindahan panas (m2)

\section{Konveksi Paksa}

Konveksi Paksa yaitu perpindahan panas suatu fluida yang diakibatkan oleh energi luar, misal menggunakan fan. Jenis aliran dalam konveksi paksa adalah laminar, transisi dan turbulen. Jenis aliran dapat diketahui dengan menentukan Bilangan Reynold. Untuk Bilangan Reynold aliran di dalam saluran aliran silang :

$\begin{array}{lll}\mathrm{u} & = & \text { Kecepatan aliran } \\ \mathrm{x} & = & \text { Jarak dan tepi depan } \\ \mathrm{v} & = & \text { Viskositas kinematis } \\ \dot{m} & = & \text { Laju aliran massa } \\ \mathrm{D} & = & \text { Diameter saluran }\end{array}$

Aliran Laminer bila $\mathrm{Re}<2300$

Aliran Transisi bila $2300<\operatorname{Re}<4000$

Aliran Turbulen bila Re $>4000$

\section{Angka Prandtl}

Angka Prandtl adalah parameter yang menghubungkan ketebalan relative antara lapisan batas hidrodinamis dan lapisan batas thermal.

$$
\operatorname{Pr}=\frac{v}{\alpha}=\frac{\mu / \rho}{k / \rho C_{p}}=\frac{\mu C_{p}}{k}
$$

\section{Bilangan Nusselt}

Bilangan yang menghubungkan antara bilangan Reynold dan Angka Prandtl. Untuk menghitung bilangan nusselt dalam pipa pada aliran turbulen digunakan persamaan Dittus-Boelter.

$$
\begin{aligned}
& \text { Dimana : } N u_{x}=\frac{h x}{k}=0,0023 \operatorname{Re}_{x}{ }^{4 / 5} \operatorname{Pr}^{n} \\
& \mathrm{n}=0,4 \text { untuk pemanas } \\
& \mathrm{n}=0,3 \text { untuk pendingin } \\
& \text { persamaan diatas hanya dapat digunakan, jika : } \\
& \text { - } 0,6 \leq \operatorname{Pr} \leq 160 \quad \bullet \quad \frac{L}{D} \geq 10 \\
& \text { - } \operatorname{Re} \geq 10,000
\end{aligned}
$$

\section{Perpindahan Panas Gabungan ${ }^{3}$ \\ Koefisien Perpindahan Panas Gabungan pada bidang datar}

\footnotetext{
${ }^{3}$ Perpindahan Panas Gabungan ,Komarudin, Ir.MT
} 


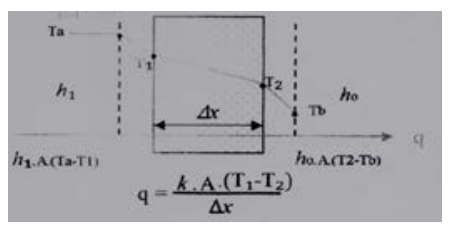

Gambar 6. Perpindahan Panas Gabungan.

(Sumber : Yunus A Cangel, Heat Transfer, A Practical Approach,2002)

Perpindahan panas gabungan pada bidang datar, seperti pada gambar 6, perhitungan laju perpindahan panasnya adalah:

$$
\mathrm{Q}=\quad \text { U.A. } \Delta \mathrm{Tm}
$$

dimana :

$\mathrm{U}=$ Koefisien perpindahan panas gabungan

A = Luas Bidang aliran panas

$\Delta \mathrm{Tm}=$ Beda Temperatur rata-rata

Laju perpindahan panas gabungan menjadi :

$\mathrm{Q}=\mathrm{h} 1 \mathrm{~A}\left(\mathrm{Ta}-\mathrm{T}_{1}\right)=\mathrm{k} \cdot \mathrm{A}\left(\mathrm{T}_{1}-\mathrm{T}_{2}\right) / \Delta \mathrm{x}$

$=\operatorname{ho} \cdot A\left(T_{2}-T_{b}\right)$

Jika disesuaikan dengan analogi listrik, maka:

$$
q=\frac{A \cdot \Delta T}{R_{k v i}+R_{k d}+R_{k v o}} \quad \begin{aligned}
& R_{k v i}=1 / h_{1} A \\
& R_{k d}=\Delta x / k A \\
& R_{k v o}=1 / h_{o} A
\end{aligned}
$$

Koefisien perpindahan panas gabungan :

$$
U=1 / h_{1}+\Delta x / k+1 / h_{o}
$$

\section{Koefisien Perpindahan Panas Gabungan pada pipa atau silinder ${ }^{4}$}

Koefisien perpindahan panas menyeluruh untuk sebuah pipa dapat pula ditemukan seperti cara diatas. Perlu diperhatikan bahwa luas permukaan yang menerima kalor pada pipa/silinder tidaklah sama untuk ke dua fluida, fluida yang satu luas permukaannya didasarkan pada permukaan dalam pipa/silinder dan fluida yang lain didasarkan pada permukaan luar pipa seperti pada gambar 7 dan 8 .

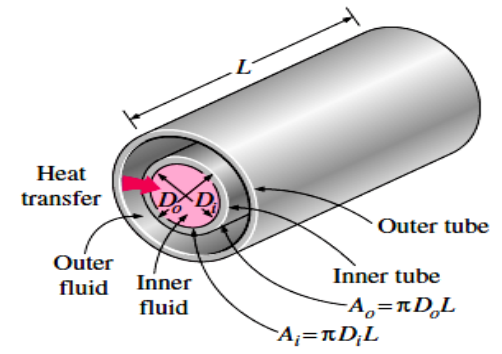

Gambar 7. Aliran fluida didalam Pipa/Silinder. (Sumber : Yunus A Cangel, Heat Transfer, A Practical Approach,2002)

\footnotetext{
42 Perpindahan Panas Dasar, Komarudin, hal 145 s/d 147
}

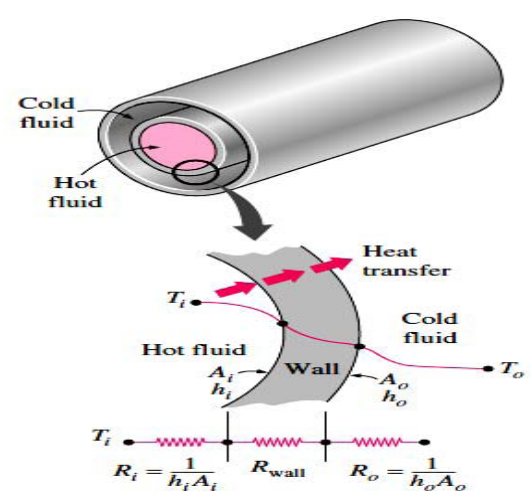

Gambar 8. Tahanan panas pada laju perpindahan panas gabungan.

(Sumber : Yunus A Cangel, Heat Transfer, A Practical Approach,2002)

Dimana:

$\mathrm{A}=$ Transfer kalor secara konveksi dari fluida dalam pipa ke permukaan bagian dalam pipa

$\mathrm{B}=$ Transfer kalor secara konduksi dari permukaan bagian dalam ke permukaan bagian luarpipa

$\mathrm{C}=$ Transfer kalor secara konveksi dari permukaan bagian luar pipa ke udara fluida yang berada di sekitar pipa

T0 = Temperatur fluida didalam pipa

$\mathrm{Ti}=$ Temperatur permukaan dinding bagian dalam pipa

$\mathrm{T} 2$ = Temperatur permukaan dinding bagian luar pipa

$\mathrm{T} 3$ = Temperatur fluida di luar pipa

$\mathrm{L} \quad=$ Panjang pipa

r0 = Jari jari bagian dalam pipa

ri = Jari jari bagian luar pipa

Dengan asumsi bahwa sumber panas berada didalam pipa/silinder, sehingga:

Aliran panas yang terjadi dari fluida ke permukaan bagian dalam pipa adalah

$$
q_{A}=h_{A} A_{A}\left(T_{0}-T_{1}\right)
$$

Aliran panas dari permukaan bagian dalam ke permukaan bagian luar adalah,

$$
\boldsymbol{q}_{B}=-\frac{T_{2}-T_{1}}{\left(\frac{\Delta x}{2 \pi L k_{B}}\right)}
$$

Aliran panas dari permukaan bagian luar ke fluida di sekeliling pipa adalah,

$$
q_{c}=h_{c} A_{C}\left(T_{2}-T_{3}\right)
$$

Jika ketiga persamaan diatas dijumlahkan pada arah temperatur maka akan menjadi :

$$
\left(T_{0}-T_{3}\right)=\frac{q_{A}}{h_{A} A_{0}}+\frac{q_{B}}{\frac{\left(l n r_{0} / r_{1}\right)}{2 \pi L k_{B}}}+\frac{q_{C}}{h_{C} A_{1}}
$$

Karena $\boldsymbol{q} \boldsymbol{A}=\boldsymbol{q} \boldsymbol{B}=\boldsymbol{q} \boldsymbol{C}=\boldsymbol{q}$, maka:

$$
q=\frac{T_{0}-T_{3}}{\frac{1}{A_{0} h_{A}}+\frac{\left(l n r_{0} / r_{1}\right)}{2 \pi L k_{B}}+\frac{1}{A_{1} h_{C}}}
$$


Dimana $\boldsymbol{A} \boldsymbol{0}$ adalah luas permukaan penerima panas bagian dalam pipa/silinder dan $\boldsymbol{A 1}$ adalah luas permukaan penerima panas permukaan luar pipa/silinder, sehingga koefisien perpindahan panas menyeluruh untuk pipa dapat ditulis :

$$
U=\frac{1}{\frac{1}{A_{0} h_{A}}+\frac{\left(l n r_{0} / r_{1}\right)}{2 \pi L k_{B}}+\frac{1}{A_{1} h_{C}}}
$$

Untuk ketebalan dinding pipa/silinder diabaikan, maka :

$$
\frac{1}{U} \approx \frac{1}{h_{A}}+\frac{1}{h_{C}}
$$

Karena luas permukaan penerima kalor berbeda pada bagian dalam dan luar pipa maka koefisien perpindahan panas menyeluruh dapat didasarkan pada permukaan luar ataupun permukaan dalam dari pipa.

$$
\begin{gathered}
U_{0}=\frac{1}{\frac{1}{h_{A}}+\frac{A_{0}\left(l n n_{0} / r_{1}\right)}{2 \pi L k_{B}}+\frac{A_{0}}{A_{1}} \frac{1}{h_{C}}} \\
U_{1}=\frac{1}{\frac{A_{1}}{A_{0}} \frac{1}{h_{A}}+\frac{A_{1}\left(l n r_{0} / r_{1}\right)}{2 \pi L k_{B}}+\frac{1}{h_{C}}}
\end{gathered}
$$

\section{Aliran Perpindahan Panas}

Aliran perpindahan panas cooler pada tungku induksi ini adalah jenis aliran silang (cross flow), seperti pada gambar 9 .

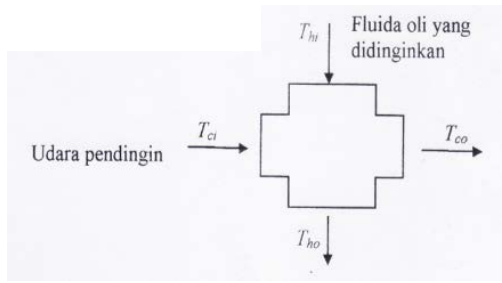

Gambar 9. Jenis Aliran Silang

(Sumber : Yunus A Cangel, Heat Transfer, A Practical Approach,2002)

Perpindahan panas yang terjadi pada sistim silang konveksi paksa adalah

$$
\mathrm{Q}=\mathrm{U}_{0} \text {.A.LMTD }
$$

Dimana :

$\mathrm{U}_{0} \quad=$ Koefisien perpindahan panas menyeluruh

A $=$ Luas permukaan perpindahan panas

LMTD = Beda temperature rata-rata logaritmik

Dimana:

$$
L M T D=F \times \frac{\left(T_{h i}-T_{c o}\right)-\left(T_{h o}-T_{c i}\right)}{\ln \left(\frac{T_{h i}-T_{c o}}{T_{h o}-T_{c i}}\right)}
$$

$\mathrm{F}=$ Faktor koreksi garis antara $\mathrm{P}$ dan $\mathrm{R}$

Dimana: $\quad P=\frac{T_{c o}-T_{h i}}{T_{h i}-T_{c i}} \quad R=\frac{T_{h i}-T_{h o}}{T_{c o}-T_{c i}}$

$\mathrm{T}_{\mathrm{ci}}=$ Temperatur masuk

$\mathrm{T}_{\mathrm{co}}=$ Temperatur keluar

$\mathrm{T}_{\mathrm{hi}}=$ Temperatur oli masuk

$\mathrm{T}_{\mathrm{ho}}=$ Temperatur oli keluar

\section{Sistem Kerja Cooling tower}

Cooling tower berfungsi sebagai pendingin untuk core pada dinding furnace dan juga untuk pendingin coolant (cairan pendingin) untuk mendinginkan VIP Panel, dapat dilihat pada gambar 10.

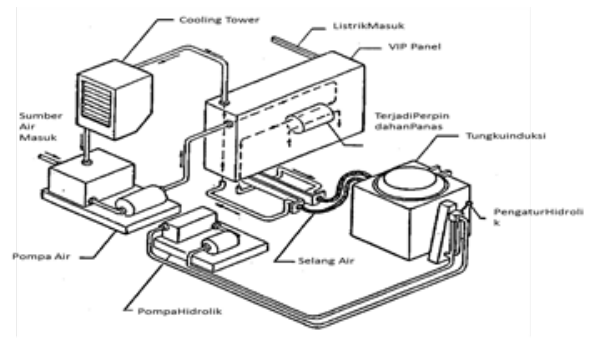

Gambar 10. Skema sirkulasi air cooling tower dan sistim hidrolik.

(Sumber : Manual book VIP Inductoterm, German)

\section{Cooling tower}

Cooling tower merupakan salah satu sistim pendingin yang mendinginkan media pendingin sampai bertemperatur mendekati temperatur bola basah udara sekitar. Output cooling tower nantinya akan digunakan kembali untuk menyuplai air yang telah didinginkan ke coil pada tungku furnace dan untuk proses heat exchanger coolant (aquades) VIP panel. Cooling tower yang digunakan adalah cooling tower dengan metode udara paksa dengan menggunakan exhaust fan, berikut spesifikasinya pada gambar 11 .

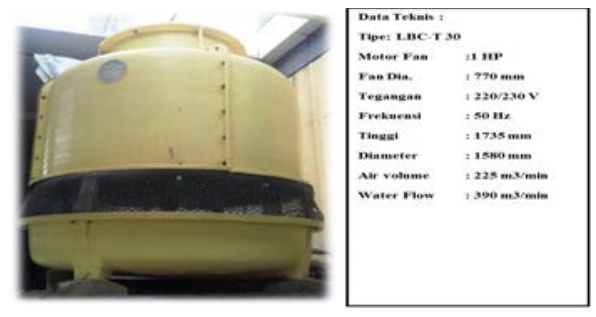

Gambar 11. Cooling tower Liang Chi. (Sumber : Liang Chi .CO.LTD, China)

\section{Tungku Induksi}

Disini coil pada dinding furnace berperan mengalirkan listrik untuk menginduksi logam dan juga karena coil ini mempunyai bentuk seperti pipa (coreless) tempat mengalirnya air dari cooling tower yang berfungsi untuk menjaga temperatur kerja coil dan dinding furnace, seperti yang terlihat pada gambar 12.

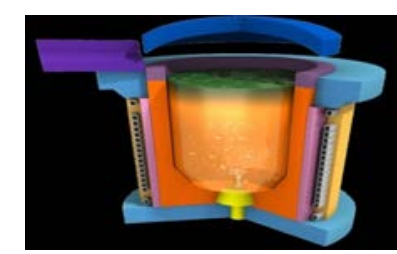

Gambar 12. Ilustrasi lapisan tungku induksi (Sumber: Induction Furnace, Capital refractories LTD, UK). 


\section{METODE DAN PENGOLAHAN DATA Metode penelitian}

Tahapan proses yang dilakukan pada penelitian ini seperti tergambar pada gambar 13 . diagram alur proses pengerjaan.

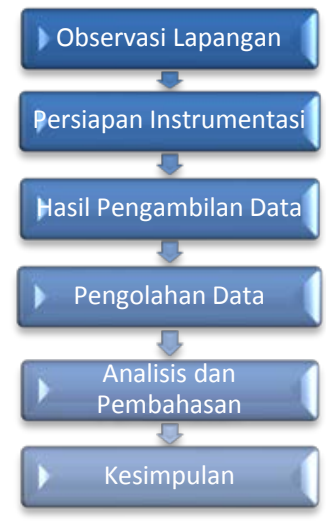

Gambar 13. Diagram Alur Proses Pengerjaan

\section{Hasil Pengambilan Data}

Penelitian dilakukan pada saat unit beroperasi melebur material logam alumunium. Setelah melakukan observasi dan melakukan pengukuran pada object penelitian. Maka didapat hasil pengambilan data, yaitu:

\section{Dimensi dinding tungku induksi pada VIP panel}

Setelah melakukan pengukuran dan spesifikasi pada katalog furnace, maka didapatkan dimensi dari tungku induksi seperti pada gambar 14 .

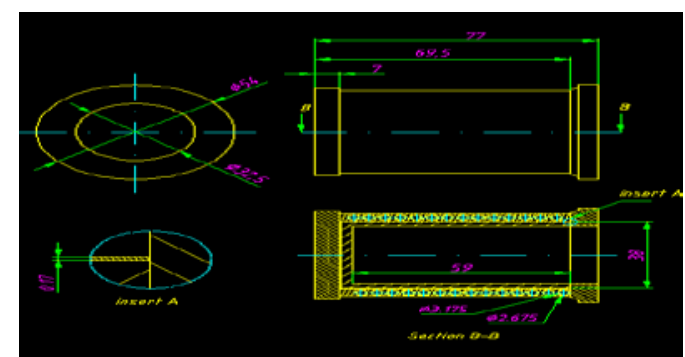

Gambar 14. Dimensi Tungku Induksi.

\section{Submersible Pump}

Cooling tower ini menggunakan pompa merk EBARRA seperti yang terlihat pada gambar 15, dengan spesifikasi sebagai berikut :

50X40 FSHA / flow rate $0.32 \mathrm{m3} / \mathrm{min} /$ Head: 55.5 m / Power: 0.75 KW/ 380 V/ 3 Phase/ 50 HZ/ 2 Pole/ 2950 RPM.

\section{Temperatur pada cooling tower}

Temperatur udara masuk

$\mathrm{Tdb} 35,6{ }^{\circ} \mathrm{C} / \mathrm{RH} 89 \%$ / Twb 33,78 ${ }^{\circ} \mathrm{C} / \mathrm{H} 121.730$ $\mathrm{Kj} / \mathrm{Kg} / \mathrm{Sv} 0,9218 \mathrm{~m} 3 / \mathrm{Kg}$

Temperatur udara keluar

Tdb $29.3{ }^{\circ} \mathrm{C} / / \mathrm{RH} 61 \%$ / Twb 23,2 ${ }^{\circ} \mathrm{C} / \mathrm{H} 69.459$ $\mathrm{Kj} / \mathrm{Kg} / \mathrm{Sv} 0,8784 \mathrm{~m} 3 / \mathrm{Kg}$

Temperatur air masuk: $28^{\circ} \mathrm{C}$
Temperatur air keluar : $25^{\circ} \mathrm{C}$

Temperatur pada tungku induksi

Temperatur dinding dalam : $\quad 443.8^{\circ} \mathrm{C}$

Temperatur dinding luar : $32.1^{\circ} \mathrm{C}$

\section{Pengolahan data}

\section{Cooling tower Performance}

\section{Range}

CT Range $\left({ }^{\circ} \mathrm{C}\right)$

$=\left[\mathrm{CW}\right.$ inlet temp $\left({ }^{\circ} \mathrm{C}\right)-\mathrm{CW}$ outlet temp $\left.\left({ }^{\circ} \mathrm{C}\right)\right]$

$=28^{\circ} \mathrm{C}-25^{\circ} \mathrm{C} \quad=3^{\circ} \mathrm{C}$

\section{Approach \\ CT Approach $\left({ }^{\circ} \mathrm{C}\right)$ \\ $=\left[\mathrm{CW}\right.$ outlet temp $\left({ }^{\circ} \mathrm{C}\right)-$ Wet bulb temp $\left.\left({ }^{\circ} \mathrm{C}\right)\right]$ \\ $=25^{\circ} \mathrm{C}-23,2^{\circ} \mathrm{C}$ $=1,8^{\circ} \mathrm{C}$}

\section{Effectiveness (aktual)}

Efektivitas CT (\%)

$=100 \%$ xRange $/($ Range + Approach $)$

$=100 \% \times\left(3^{\circ} \mathrm{C}\right) /\left(3^{\circ} \mathrm{C}+1,8^{\circ} \mathrm{C}\right)=62.5 \%$

\section{Cooling Capacity}

Cooling capacity $=$ Mass flow rate of water $\mathrm{x}$ specific heat $x$ Range

$$
\begin{aligned}
& =5.33 \mathrm{~kg} / \mathrm{hr} \times 1 \mathrm{cal} / \mathrm{gr}^{\circ} \mathrm{C} \times 3^{\circ} \mathrm{C} \\
& =15990 \mathrm{cal} / \mathrm{s}=15.99 \mathrm{kcal} / \mathrm{s}
\end{aligned}
$$

\section{Evaporation loss}

Evaporation loss $=0,00085 \times 1,8 \times$ Circulation rate $(\mathrm{m} 3 / \mathrm{hr}) \times \Delta \mathrm{T}\left({ }^{\circ} \mathrm{C}\right)$

$=0,00085 \times 1,8 \times 0,32 \mathrm{~m} 3 / \mathrm{hr} \times 3^{\circ} \mathrm{C}$

$=0,0014688 \mathrm{~m}^{3} / \mathrm{hr}$

Cycles of concentration (C.O.C)

Cycles of concentration (C.O.C) = 6cycles

Blow down losses

Blow down losses

= Evaporation loss / (C.O.C. -1 )

$=0,0014688 /(6$ cycles -1$)$

$=0,00029376 \mathrm{~m}^{3} / \mathrm{hr}$

\section{Liquid/Gas (L/G) ratio}

$(\mathrm{L} / \mathrm{G})$ ratio $=(\mathrm{Hao}-\mathrm{Hwb}) / \mathrm{Cp}(\mathrm{T} 1-\mathrm{T} 2)$

$$
\begin{array}{ll}
= & \frac{(121.730-69.459(\mathrm{kj} / \mathrm{kg}))}{\left(4,1784 \times 10^{-3}\right) \times 3^{\circ} \mathrm{C}} \\
= & 4169.94 \mathrm{kj} / \mathrm{kg}^{\circ} \mathrm{C}
\end{array}
$$

\section{Perhitungan penyerapan kalor pada dinding} tungku dan coil

Suhu permukaan coil (Ts)

Diketahui :

$$
\begin{array}{lc}
\text { pair }=997,0479 \mathrm{~kg} / \mathrm{m}^{3} & D=1 \frac{1}{4} \text { inch }=0,03175 \mathrm{~m} \\
\mathrm{k}=0,58 \mathrm{~W} / \mathrm{m}^{\circ} \mathrm{C} & \Delta \text { 回 }=(28 \text { 回 }-25 \text { 回 })=3 \text { 回 } \\
\mathrm{V}_{\text {air }}=0,32 \mathrm{~m}^{3} / \min =5, . & \mathrm{Cp}=4,1784 \times 10^{-3} \mathrm{kj} /\left(\mathrm{kg}^{\circ} \mathrm{C}\right)
\end{array}
$$


Luas area permukaan perpindahan panas coil (Ac \&As):

Ac $=\frac{1}{4} \pi D^{2}=\frac{1}{4} \pi(0,03175 m)^{2}$

$=7,9 \times 10^{-4} \mathrm{~m}^{2}$.(luas diameter pipa )

$\mathrm{As}=\pi \mathrm{DL}=\pi(0,03175 \mathrm{~m})(18,9 \mathrm{~m})$

$=1,885 \mathrm{~m}^{2} \quad \ldots$ (luas keliling pipa )

Laju aliran massa air (mass flow rate):

$\mathrm{m}=\rho . \mathrm{V}$

$=997.0479 \mathrm{~kg} / \mathrm{m}^{3} \times 0,32 \mathrm{~m}^{3} / \mathrm{min}$

$=319,055 \mathrm{~kg} / \min =5,32 \mathrm{~kg} / \mathrm{s}$

Panas yang diberikan ke air sebesar (asumsi panas seragam di seluruh permukaan pipa).

Qair $=\mathrm{m} \mathrm{Cp}(\Delta \mathrm{T})$

$=5,32 \mathrm{~kg} / \mathrm{s} \times\left(4,1813 \times 10^{-3}\right) \mathrm{kj} / \mathrm{kg}^{\circ} \mathrm{C} \times 3^{\circ} \mathrm{C}$

$=0,0667 \mathrm{kj} / \mathrm{s}=0,0667 \mathrm{~kW}$

Semua energi panas dari cooling tower untuk merubah temperatur air menjadi $28^{\circ} \mathrm{C}$ yaitu sebesar $0,0667 \mathrm{~kW}$.

Ts adalah suhu permukaan pipa coil, dapat ditentukan dari:

$$
\mathrm{q}_{\mathrm{s}}=\mathrm{h}(\mathrm{Ts}-\mathrm{Tm}) \rightarrow \mathrm{Ts}=\mathrm{Tm}+\frac{\mathrm{q}_{\mathrm{s}}}{\mathrm{h}}
$$

Dimana $\mathrm{h}$ adalah koefisien perpindahan panas dan Tm adalah suhu rata-rata air.

Fluks panas $\left(\mathrm{q}_{\mathrm{s}}\right)$ permukaan dalam hal ini konstan, dan dapat ditentukan dari:

$q_{s}=$ Qair $/_{\text {As }}=0,0667 \mathrm{~kW} / 0,6 \mathrm{~m}^{2}=0,035 \mathrm{~kW} / \mathrm{m}^{2}$

Untuk menentukan koefisien perpindahan panas, pertama kita perlu mencari kecepatan rata-rata air:

$$
\begin{aligned}
V m & =V_{\text {air }} /_{A c}=\frac{0,32 \mathrm{~m}^{3} / \min }{7,9 \times 10^{-4} \mathrm{~m}^{2}}=405,06 \mathrm{~m} / \mathrm{min} \\
& =6,751 \mathrm{~m} / \mathrm{s}
\end{aligned}
$$

$v$ adalah kecepatan kinematik air, yang nilainya didapat dari:

$$
v=\mu / \rho=\frac{7,978 \times 10^{-4} \mathrm{~kg} / \mathrm{ms}}{997,0479 \mathrm{~kg} / \mathrm{m}^{3}}=8 \times 10^{-7} \mathrm{~m}^{2} / \mathrm{s}
$$

Dimana $\mu$ adalah kecepatan dinamik air (terdapat pada tabel water properties),

maka kita dapat mencari bilangan Reynold:

$$
\operatorname{Re}=\frac{V m D}{v}=\frac{6,751 \mathrm{~m} / \mathrm{sx} 0,03175 \mathrm{~m}}{8 \times 10^{-7} \mathrm{~m}^{2} / \mathrm{s}}=267.876,01
$$

Re $>$ 10.000. oleh karena itu, aliran turbulen, asumsi berkembang turbulen pada seluruh pipa dan menentukan bilangan Prandtl:

$\operatorname{Pr}=\frac{v}{\alpha}=\frac{8 \times 10^{-7} \mathrm{~m}^{2} / \mathrm{s}}{0,143 \times 10^{-6} \mathrm{~m}^{2} / \mathrm{s}}=5,59$

Dimana $\propto$ adalah difusivitas thermal.

Maka kita dapat mencari bilangan Nusseltnya :

$$
\begin{aligned}
\mathrm{Nu} & =\frac{\mathrm{hD}}{\mathrm{k}}=0,023 \mathrm{Re}^{0.8} \mathrm{Pr}^{0.4} \\
& =0,023 \times 267.876,01^{0.8} \times 5,59^{0.4} \\
& =1007,02
\end{aligned}
$$

Maka kita dapat mencari koefisien perpindahan panas (h):

$$
\begin{aligned}
& \mathrm{h}=\frac{\mathrm{k}}{\mathrm{D}} \mathrm{Nu}=\frac{0,58 \mathrm{~W} / \mathrm{m}^{\circ} \mathrm{C}}{0,03175 \mathrm{~m}} \times 1007,02 \\
& =18.396 \mathrm{~W} / \mathrm{m}^{2}{ }^{\circ} \mathrm{C}=18,4 \mathrm{~kW} / \mathrm{m}^{2}{ }^{\circ} \mathrm{C}
\end{aligned}
$$

h konveksi pada pipa coil adalah sebesar 18,4 kW / $\mathrm{m}^{\circ} \mathrm{C}$, maka dapat kita hitung temperatur pada dalam permukaan pipa:

$$
\begin{aligned}
\mathrm{Ts} & =\mathrm{Tm}+\frac{\mathrm{q}_{\mathrm{s}}}{\mathrm{h}}=28{ }^{\circ} \mathrm{C}+\frac{0,035 \mathrm{~kW} / \mathrm{m}^{2}}{18,39 \mathrm{~kW} / \mathrm{m}^{\circ} \mathrm{C}} \\
& =28^{\circ} \mathrm{C}+\left(1,9 \times 10^{-3}\right){ }^{\circ} \mathrm{C}=28^{\circ} \mathrm{C}
\end{aligned}
$$

\section{Perpindahan panas pada dinding tungku induksi}

Untuk mencari perpindahan panasa yang terjadi pada keseluruhan lapisan dinding tungku induksi maka kita harus mencari koefisien perpindahan panas gabungan (U), dengan diketahui ;

$$
\Delta \mathrm{T}=\left(443.8^{\circ} \mathrm{C}-32.1^{\circ} \mathrm{C}\right)=411,7^{\circ} \mathrm{C}
$$

Konduktifitas thermal dan dan tebal lapisan dinding:

- Crusible CRL65; $\mathrm{k}=2,1 \mathrm{~W} / \mathrm{m}^{\circ} \mathrm{C} ; \mathrm{t}=27,5 \mathrm{~mm}$

- $\quad$ Mica Slip Pane; $\mathrm{k}=0,07 \mathrm{~W} / \mathrm{m}^{\circ} \mathrm{C} ; \mathrm{t}=3,8 \mathrm{~mm}$

- Gypsum board; $\mathrm{k}=0,17 \mathrm{~W} / \mathrm{m}^{\circ} \mathrm{C} ; \mathrm{t}=31,75 \mathrm{~mm}$

- Tembaga (coil); $\mathrm{k}=400 \mathrm{~W} / \mathrm{m}^{\circ} \mathrm{C} ; \varnothing=$ $31,75 \mathrm{~mm}$

$$
\begin{aligned}
& \Sigma \mathrm{R}=\Sigma \frac{\mathrm{X}}{\mathrm{K}}+\frac{1}{\mathrm{hkonveksi}} \\
& =\frac{27,5 \mathrm{~mm}}{2,1 \mathrm{~W} / \mathrm{m}^{\circ} \mathrm{C}}+\frac{3,8 \mathrm{~mm}}{0,07 \mathrm{~W} / \mathrm{m}^{\circ} \mathrm{C}}+\frac{31,75 \mathrm{~mm}}{0,17 \mathrm{~W} / \mathrm{m}^{\circ} \mathrm{C}} \\
& +\frac{10 \mathrm{~mm}}{400 \mathrm{~W} / \mathrm{m}^{\circ} \mathrm{C}}+\frac{1}{18.391,2 \mathrm{~W} / \mathrm{m}^{\circ} \mathrm{C}}
\end{aligned}
$$




$$
\begin{aligned}
& =0,013 \mathrm{~m}^{2 \circ} \mathrm{C} / \mathrm{W}+0,054 \mathrm{~m}^{2 \circ} \mathrm{C} / \mathrm{W}+0,186 \mathrm{~m}^{2 \circ} \mathrm{C} / \mathrm{W} \\
& +2,5 \times 10^{-5} \mathrm{~m}^{2 \circ} \mathrm{C} / \mathrm{W}+\ldots 5,44 \times 10^{-5} \mathrm{~m}^{2 \circ} \mathrm{C} / \mathrm{W} \\
& =0,253 \mathrm{~m}^{2 \circ} \mathrm{C} / \mathrm{W} \\
& U=\frac{1}{\Sigma R}=\frac{1}{0,253 \mathrm{~m}^{2 \circ} \mathrm{C} / \mathrm{W}}=3,953 \mathrm{~W} / \mathrm{m}^{2 \circ} \mathrm{C}
\end{aligned}
$$

Luas penampang (A) di asumsikan adalah keliling lingkaran dari tungku induksi diambil dari total tebal lapisan dinding dikalikan dengan tinggi dinding tungku.

$$
\begin{aligned}
A & =\pi D H \\
& =\pi 451,1 \mathrm{mmx} 625 \mathrm{~mm} \\
& =885.283,75 \mathrm{~mm}^{2}=0,885 \mathrm{~m}^{2}
\end{aligned}
$$

LMTD pada konfigurasi aliran bersilangan (cross flow) : LMTD $=F x \frac{\left(T_{\text {hi }}-T_{c o}\right)-\left(T_{h o}-T_{c i}\right)}{\ln \left(\frac{\left(T_{\text {hi }}\right)-\left(T_{c o}\right)}{\left(T_{h o}\right)-\left(T_{c i}\right)}\right)}=89,645^{\circ} \mathrm{C}$

Dimana :

$\mathrm{T}_{\mathrm{ci}}=$ Temperatur masuk

$\mathrm{T}_{\mathrm{co}}=$ Temperatur keluar

$\mathrm{T}_{\mathrm{hi}}=$ Temperatur dinding dalam $\left(443,8^{\circ} \mathrm{C}\right)$

$\mathrm{T}_{\mathrm{ho}}=$ Temperatur dinding luar $\quad\left(32,1^{\circ} \mathrm{C}\right)$

$\mathrm{F}=$ Faktor koreksi (asumsi 1 = kondensor $/$ pendingin)

Maka kita dapat mencari laju perpidahan panas gabungan dari tungku induksi :

$$
\begin{aligned}
& Q_{\text {gabungan }}=\mathrm{U} \cdot \mathrm{A} \cdot \Delta \mathrm{T}_{\mathrm{LMTD}} \\
& \begin{array}{r}
=3,953 \mathrm{~W} / \mathrm{m}^{2}{ }^{\circ} \mathrm{C} \times 0,885 \mathrm{~m}^{2} \times 89,645^{\circ} \mathrm{C} \\
=313,715 \mathrm{~W}=0,313 \mathrm{Kw}
\end{array}
\end{aligned}
$$

\section{Skema sirkulasi aliran air pada cooling tower}

Sirkulasi dari cooling tower ke tungku induksi dapat kita lihat pada gambar 16.

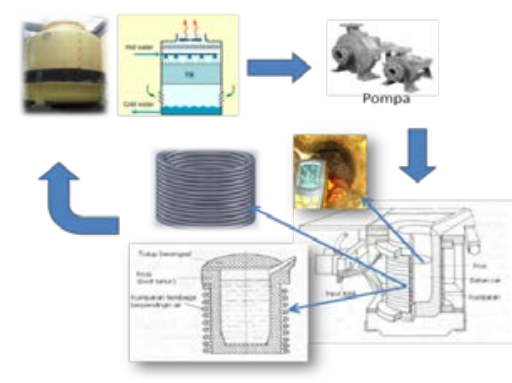

Gambar 16. Skema sirkulasi air cooling tower pada tungku induksi

\section{Perbandingan Liquid/Gas (L/G) test dan design}

$$
\begin{gathered}
\text { - Design } G=\frac{q_{\text {udara }}}{s v}=4,26 \mathrm{~kg} / \mathrm{s} ; L=\rho \times \text { Vair }=6,48 \mathrm{~kg} / \mathrm{s} \\
\mathrm{L} / \mathrm{G} \text { Design }=1,521 \\
\text { - Test } G=\frac{q_{\text {udara }}}{s v}=4,26 \mathrm{~kg} / \mathrm{s} ; L=\rho \times \text { Vair }=5,314 \mathrm{~kg} / \mathrm{s} \\
\mathrm{L} / \mathrm{G}^{\text {Test }}=1,247
\end{gathered}
$$

Maka efisiensi dari cooling tower,

$$
\begin{aligned}
\text { Efisiensi } & =\frac{(L / G) \text { test }}{(L / G) \text { design }} \times 100 \% \\
& =\frac{1,247}{1,521} \times 100 \% \\
& =81,98 \%
\end{aligned}
$$

\section{KaV/L karakteristik Cooling tower}

Nilai k.a.V/L merupakan salah satu indikator untuk menyatakan karakteristik sebuah cooling tower atau merupakan angka yang menunjukan besar tranfer unit cooling tower tsb.Untuk mendapatkan karakteristik cooling tower harus dilakukan pengujian dengan membuat variasi laju aliran.

Secara perhitungan karakteristik cooling tower dapat diperoleh melalui metoda Tchebyceff dengan integrasi numeric yang telah dikonversi dalam persamaan, sebagai berikut :

$$
\begin{aligned}
& \frac{K a V}{L}=\frac{T c w}{T h w} \frac{d t}{H a O-H w b} \\
& \frac{K a V}{L}=\frac{T h w-T c w}{4} \times \sum \frac{1}{\Delta H} \\
& \Delta H=\Delta(H w-H a)
\end{aligned}
$$

Maka dapat dihitung $\Delta \mathrm{H}$,

$$
\Delta \mathrm{H}=121,730-69,459=52,271
$$

Setelah mendapatkan $\Delta \mathrm{H}$ maka selanjutnya kita melakukan pecobaan untuk mendapatkan nilai 1/(Hwb-Hao), seperti yang tercantum dalam tabel 2.

Tabel 2. Percobaan 1/(Hwb-Hao)

\begin{tabular}{|c|c|c|c|}
\hline \multicolumn{3}{|c|}{ Percobaan } \\
\hline No & Hwb & Hao & $1 /$ (Hwb-Hao) \\
\hline 1 & 91.59 & 92.12 & 1.876 \\
\hline 2 & 91.43 & 92.12 & 1.445 \\
\hline 3 & 91.17 & 92.33 & 0.863 \\
\hline 4 & 90.84 & 92.66 & 0.549 \\
\hline
\end{tabular}

Setelah melakukan percobaan, masukkan nilai tersebut dalam persamaan,

$$
\begin{aligned}
\frac{K a V}{L} & =\frac{35,6-29.3}{4} \times(1,876+1,445+0,863+0,549) \\
\frac{K a V}{L} & =1,575 \times 4,733 \\
\frac{K a V}{L} & =7,45^{\mathrm{kg}} \mathrm{C} / \mathrm{kJ}
\end{aligned}
$$

Maka dipatkan nilai karakteristik cooling tower

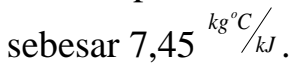




\section{Kurva Karakteristik K.a.V/L : L/G}

Karakteristik design cooling tower dimuat dalam kurva hubungan K.a.V/L dengan rasio L/G pada berbagai temperatur udara wet bulb dan range. Kurva ini untuk perancangan cooling tower dengan menentukan besar temperatur Wet bulb udara, Range dan Approach, seperti pada gambar 17.

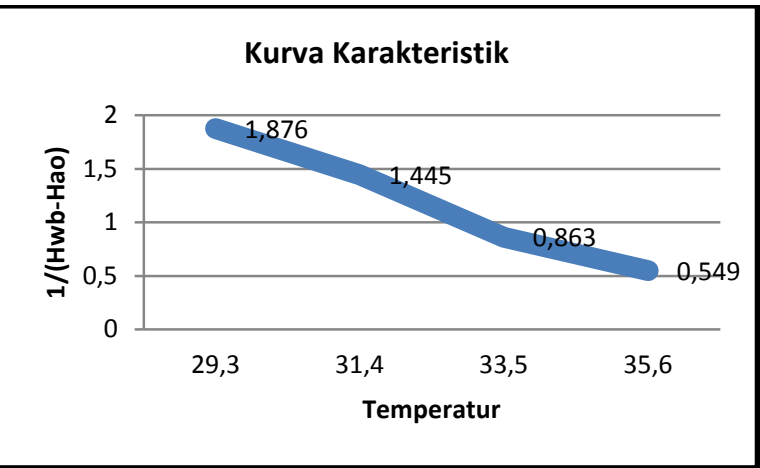

Gambar 17. Grafik Kurva Karakteristik K.a.V/L : $\mathrm{L} / \mathrm{G}$

\section{ANALISIS DAN PEMBAHASAN}

\section{Hasil Pengolahan Data}

Setelah melakukan observasi dilapangan pada cooling tower dan pengolahan data, maka didapatkan data seperti yang tercantum dalam tabel 3 Penyerapan kalor gabungan.

Tabel 3. laju perpindahan panas gabungan.

\begin{tabular}{|c|c|c|}
\hline $\begin{array}{l}\text { Laju perpindahan panas } \\
\text { gabungan }\end{array}$ & & \\
\hline$\Sigma R$ & 0.2542 & $\left(m 2^{\circ} \mathrm{C}\right) / W$ \\
\hline$U$ & 3.934 & $\mathrm{~W} / \mathrm{m} 2{ }^{\circ} \mathrm{C}$ \\
\hline \multicolumn{3}{|c|}{$\begin{array}{c}\text { LMTD (perbedaan temperature rata-rata } \\
\text { logaritmik) }\end{array}$} \\
\hline LMTD & 89.64 & ${ }^{\circ} \mathrm{C}$ \\
\hline \multirow{2}{*}{ Q Refractories } & 156.07 & $W$ \\
\hline & 0.1561 & $k W$ \\
\hline Q Total & 0.223 & $\mathrm{kj} / \mathrm{s}(\mathrm{kW})$ \\
\hline
\end{tabular}

Setelah mendapatkan laju perpindahan panas dari air dan dinding tungku induksi maka diperoleh total penyerapan kalor yang terjadi adalah $0,223 \mathrm{~kW}$.

\section{Analisis Efisiensi Penyerapan Kalor \\ Analisa sebab akibat}

Pada gambar 18 dapat kita lihat analisa sebab akibat menggunakan diagram ikan (fish bone). Didapatkan kesimpulan bahwa untuk meningkatkan penyerapan kalor dari dinding furnace dan pipa coil ke air, maka improvement yang memungkinkan untuk dilakukan adalah dengan memodifikasi kecepatan aliran air pada pompa.

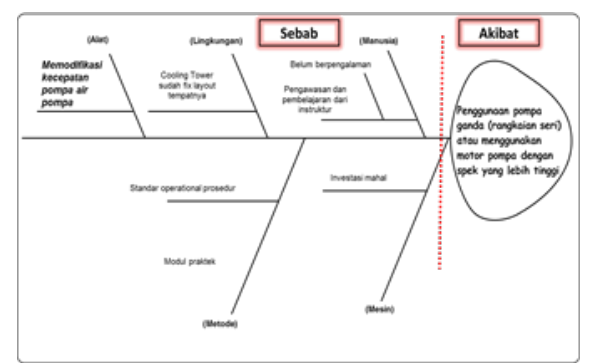

Gambar 18. Diagram Fish bone analisa sebab akibat.

Kecepatan aliran air dapat dimodifikasi adalah dengan :

1. Menggunakan 2 pompa yang dirangkai seri.

2. Mengganti pompa dengan menaikkan spesifikasi pompa 2 kali lipat.

Pembahasan selanjutnya adalah memodifikasi akecepatan aliran air dengan menggunakan 2 pompa dengan rangkaian seri.

\section{Penyerapan Kalor Rangkaian Pompa Seri}

Dari data observasi cooling tower dapat kita ketahui bahwa laju aliran air yang dipompa motor ke tanur dari cooling tower adalah $0.32 \mathrm{~m}^{3} / \mathrm{min}$, diperoleh dari data spesifik motor pompa air yang digunakan. Dari sini penulis menganalisa untuk meningkatkan kinerja dari cooling tower ini, maka dapat kita rubah kecepatan aliran air keluaran dari cooling tower. Jika laju aliran air ini lebih besar dari kapasitas sebelumnya maka dapat menghasilkan laju perpindahan panas yang lebih besar pula. Dengan merangkai 2 pompa air dengan rangkaian seri diharapkan dapat menghasilkan laju aliran air lebih besar. Dapat kita lihat dari gambar 19 berikut ini.

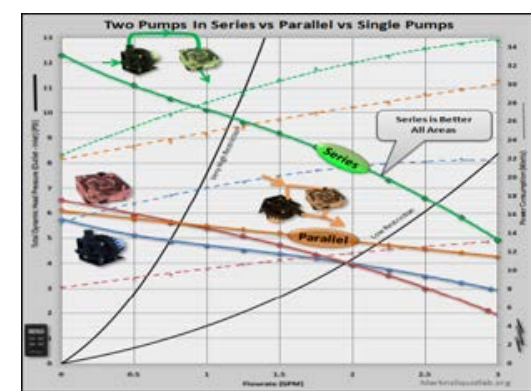

Gambar 19. Perbandingan rangkaian pompa

(Sumber: Optimasi Pengujian pompa seri dan pararel,nasirudin @poltek padang)

Setelah melakukan observasi dilapangan pada cooling tower didapatkan data seperti yang tercantum dalam tabel 4 spesifikasi temperatur keluar dan masuk cooling tower baik udara maupun air: 
Tabel 4. Data cooling tower dari psikromatrik chart.

\begin{tabular}{|c|c|c|c|c|c|}
\hline \multicolumn{6}{|c|}{ Temp. Inlet air (Psikromatrik chart) } \\
\hline$T d b$ & 35.60 & ${ }^{\circ} \mathrm{C}$ & $H$ & 121.73 & $\mathrm{Kj} / \mathrm{Kg}$ \\
\hline$R H$ & 89.00 & $\%$ & Sv & 0.92 & $\mathrm{~m}^{3} / \mathrm{Kg}$ \\
\hline$T w b$ & 33.78 & ${ }^{\circ} \mathrm{C}$ & & & \\
\hline \multicolumn{6}{|c|}{ Temp. Outlet air (Psikromatrik chart) } \\
\hline$T d b$ & 29.30 & ${ }^{\circ} \mathrm{C}$ & $H$ & 69.46 & $\mathrm{Kj} / \mathrm{Kg}$ \\
\hline$R H$ & 61.00 & $\%$ & Sv & 0.8784 & $\mathrm{~m}^{3} / \mathrm{Kg}$ \\
\hline$T w b$ & 23.20 & ${ }^{\circ} \mathrm{C}$ & Air flow & 225 & $\mathrm{~m}^{3} / \min$ \\
\hline \multicolumn{4}{|c|}{ Temp. inlet water (hot) } & 28.00 & ${ }^{\circ} \mathrm{C}$ \\
\hline \multicolumn{4}{|c|}{ Temp. Outlet Water (cold) } & 25.00 & ${ }^{\circ} \mathrm{C}$ \\
\hline \multicolumn{4}{|c|}{ Flow rate } & 0.62 & $\mathrm{~m}^{3} / \min$ \\
\hline \multicolumn{4}{|c|}{ Spesific heat $C P$} & 4.1784 & $\mathrm{kj} /\left(\mathrm{kg}^{\circ} \mathrm{C}\right)$ \\
\hline \multicolumn{4}{|c|}{$\mu$ (viscosity) 0.798 centipoise } & 0.0008 & $\mathrm{~kg} /(\mathrm{ms})$ \\
\hline \multicolumn{4}{|c|}{$\rho$ (density) } & 1,000 & $\mathrm{~kg} / \mathrm{m}^{3}$ \\
\hline \multicolumn{4}{|c|}{$\alpha$ (thermal diffusivity) } & 0.000000143 & $\mathrm{~m}^{2} / \mathrm{min}$ \\
\hline \multicolumn{4}{|c|}{ Thermal Conductivity of water $(\mathrm{k})$} & 0.58 & $W /(m \cdot K)$ \\
\hline \multicolumn{4}{|c|}{ Diameters of pipe (1 1/4 inch) } & 0.03175 & $M$ \\
\hline
\end{tabular}

Observasi yang dilakukan adalah mengukur temperatur input dan output air cooling tower dan juga temperatur udara inlet dan outlet cooling tower. setelah didapat temperatur udara kemudian diolah menggunakan psikromatrik chart maka akan didapatkan parameter dan sifat udara atmosfir pada cooling tower. Setelah melakukan observasi pada cooling tower, maka dilakukan observasi pada tanur induksi. Data yang diperoleh pada saat observasi di tanur induksi seperti yang tercantum dalam tabel 5 suhu tungku induksi dan spesifikasi lapisan dinding tungku.

Tabel 5. Data observasi tungku induksi.

\begin{tabular}{|c|c|c|}
\hline \multicolumn{3}{|l|}{ Refractories } \\
\hline Temp. inside refractories wall & 443.80 & ${ }^{\circ} \mathrm{C}$ \\
\hline Temp. outside refractories wall & 32.10 & ${ }^{\circ} \mathrm{C}$ \\
\hline$\Delta T$ (refractories) & 411.70 & ${ }^{\circ} \mathrm{C}$ \\
\hline \multicolumn{3}{|l|}{ Crusible CRL65 } \\
\hline$k$ (konduktivitas thermal) & 2.1 & $\mathrm{~W} / \mathrm{m}^{\circ} \mathrm{C}$ \\
\hline t tebal penampang & 0.0275 & $M$ \\
\hline \multicolumn{3}{|l|}{ Mica Slip Pane } \\
\hline k (konduktivitas thermal) & 0.07 & $W / m^{\circ} \mathrm{C}$ \\
\hline t tebal penampang & 0.0038 & $M$ \\
\hline \multicolumn{3}{|l|}{ Gypsum board } \\
\hline k (konduktivitas thermal) & 0.17 & $W / m^{\circ} \mathrm{C}$ \\
\hline t tebal penampang & 0.03175 & M \\
\hline \multicolumn{3}{|l|}{ Tembaga (coil) } \\
\hline k (konduktivitas thermal) & 400 & $W / m^{\circ} \mathrm{C}$ \\
\hline Diameters of pipe (1 1/4 inch) & 0.03175 & $M$ \\
\hline t tebal penampang & 0.01 & $M$ \\
\hline$D$ (Diameter of Refractories) & 0.451 & $M$ \\
\hline$H$ (Heigh of Refractories) & 0.625 & $M$ \\
\hline$A(1 / 2 \pi D H)$ & 0.443 & $m^{2}$ \\
\hline
\end{tabular}

Dari tabel 5 dapat kita lihat, temperatur permukaan dinding bagian dalam dan luar tungku induksi. Serta mecari data ketebalan dan jenis lapisan dinding tungku dari standart katalog pabrikan tungku tersebut. Kemudian dilakukan pemodelan atau design untuk dapat lebih memperjelas ukuran dari tungku induksi. Setelah mendapatkan data jenis lapidan dinding maka kita dapat mengetahui berapa konduktivitas thermal masing masing lapisan dinding untuk menghitung laju perpindahan kalor yang terjadi.

Setelah mendapatkan keseluruhan data hasil observasi maka dapat kita lakukan perhitungan manual sesuai dengan landasan teori yang telah dijabarkan pada bab II, maka didapatkan hasil seperti yang tercantum dalam tabel 6, perhitungan perpindahan kalor dari dinding coil ke air cooling tower.

Tabel 6. Perhitungan penyerapan kalor air.

\begin{tabular}{|l|l|l|}
\hline Mass flow rate & 10.67 & $\mathrm{~kg} / \mathrm{s}$ \\
\hline Range & 3.00 & ${ }^{\circ} \mathrm{C}$ \\
\hline Approach & 1.80 & ${ }^{\circ} \mathrm{C}$ \\
\hline Effectiveness (actual) & 62.5 & $\%$ \\
\hline Cooling capacity & 32.00 & $\mathrm{kcal} / \mathrm{s}$ \\
\hline Evaporation loss & 0.00294 & $\mathrm{~m} 3 / \mathrm{hr}$ \\
\hline Cycles of concentration (C.O.C) & 6 & $\mathrm{cycles}$ \\
\hline Blow down losses & 0.00059 & $\mathrm{~m} 3 / \mathrm{hr}$ \\
\hline (L/G) ratio & 4169.94 & $\mathrm{kj} / \mathrm{kg}{ }^{\circ} \mathrm{C}$ \\
\hline Q Water & 0.13 & $\mathrm{kj} / \mathrm{s}(\mathrm{kW})$ \\
\hline
\end{tabular}

Setelah mendapatkan nilai penyerapan kalor di air, maka kita bisa menghitung temperatur di permukaan dalam pipa coil dengan terlebih dahulu menetukan jenis lairan yang terjadi pada aliran air dari cooling tower ke tungku induksi seperti yang tercantum dalam tabel 7 , perhitungan penyerapan kalor air masuk dan keluar cooling tower.

Tabel 7. Temperatur dalam pipa coil.

\begin{tabular}{|c|c|c|}
\hline \multicolumn{3}{|l|}{$T_{s}$ (inner temp. of pipe) } \\
\hline Ac $\left(1 / 4 \pi D^{\wedge} 2\right)$ (in meters) & 0.000791329 & $m^{2}$ \\
\hline As $(\pi D L)$ (per meters) & 0.099695 & $m^{2}$ \\
\hline$q_{s}($ Heat flux $)$ & 1.341178595 & $\mathrm{~kW} / \mathrm{m}^{2}$ \\
\hline \multirow[t]{2}{*}{$V_{m}$ (Water Velocity rate) } & 808.7659487 & m/min \\
\hline & 13.48 & $m / s$ \\
\hline$v$ (Kinematic velocity) & 0.000000798 & $\mathrm{~m}^{2} / \mathrm{s}$ \\
\hline Re (Reynold number) & 536305.74 & \\
\hline \multicolumn{3}{|c|}{ Re $>10000$, aliran turbulance } \\
\hline Pr (Prandtl number) & 5.58041958 & \\
\hline $\mathrm{Nu}$ (Nusselt number) & 1753.575763 & \\
\hline \multirow[t]{2}{*}{ h(konveksi) } & 32033.82 & $W / m^{\circ} \mathrm{C}$ \\
\hline & 32.03382496 & $\mathrm{~kW} / \mathrm{m}^{\circ} \mathrm{C}$ \\
\hline$T_{s}$ (inner temp. of pipe) & 28.04 & ${ }^{\circ} \mathrm{C}$ \\
\hline
\end{tabular}

Temperatur dalam pipa coil yang diperoleh dari hasil perhitungan diatas dapat digunakan untuk mengetahui nilai penyerapan kalor yang terjadi pada dinding tungku induksi. Kita dapat menghitung secara keseluruhan penyerapan kalor yang terjadi pada dinding tungku induksi seperti yang tercantum dalam tabel 8. Pehitungan kalor gabungan dari air cooling tower ke dinding tungku induksi. 
Tabel 8. Temperatur dalam pipa coil.

\begin{tabular}{|l|l|l|}
\hline \multicolumn{4}{|l|}{ Laju penyerapan kalor gabungan } \\
\hline$\Sigma R$ & 0.2542 & $\left(\mathrm{~m}^{2}{ }^{\circ} \mathrm{C} / \mathrm{W}\right.$ \\
\hline$U$ & 3.934 & $\mathrm{~W} / \mathrm{m}^{2} \mathrm{C}$ \\
\hline \multicolumn{3}{|l|}{ LMTD (perbedaan temperature rata-rata logaritmik) } \\
\hline LMTD & 89.64 & ${ }^{\circ} \mathrm{C}$ \\
\hline \multirow{2}{*}{ Q Refractories } & 156.09 & $\mathrm{~W}$ \\
\cline { 2 - 3 } & 0.1561 & $\mathrm{~kW}$ \\
\hline Q Total & 0.290 & $\mathrm{kj} / \mathrm{s}(\mathrm{kW})$ \\
\hline
\end{tabular}

Setelah mendapatkan laju penyerapan kalor dari air dan dinding tungku induksi maka diperoleh total penyerapan kalor yang terjadi adalah $0,29 \mathrm{~kW}$.

\section{Analisa Efisiensi Penyerapan Kalor}

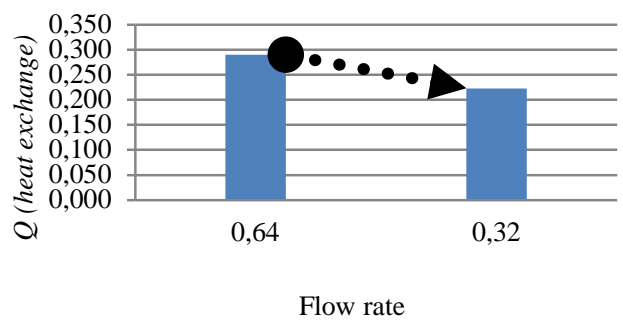

Gambar 20. Perbadingan Penyerapan kalor rangkaian pompa seri dan single.

Pada gambar 20, dapat dilihat bahwa penyerapan kalor pada rangkaian seri lebih besar dari pada rangkaian pararel. Adapun dengan penyerapan kalor yang optimal maka efisiensi cooling tower dapat terjaga pada $81.98 \%$, dan juga tidak terjadi kerusakan pada coil karena suhu kerja jauh dari suhu lebur tembaga. Disamping itu material alumunium atau molten dapat dilebur dengan baik karena proses penginduksian logam berjalan sempurna.

\section{KESIMPULAN}

Berdasarkan hasil analisa dan pengolahan data dapat disimpulkan:

1. Nilai efisiensi perfomance cooling tower adalah 81.98\%. Penyebab penurunan efisiensi kerja cooling tower karena periode penggunaannya sudah lama (beroperasi sejak 2008).

2. Dalam menstabilkan suhu kerja tungku induksi dapat dilakukan dengan Memodifikasi rangkaian motor pompa dari single manjadi double dengan rangkaian seri sehingga menambah debit air dari cooling tower ke coil tungku induksi dari awalnya $0.32 \mathrm{~m}^{3} / \mathrm{min}$ menjadi $0.64 \mathrm{~m}^{3} / \mathrm{min}$. Dengan begitu penyerapan kalor dari tungku coil ke air meningkat dari $0,223 \mathrm{~kW}$ menjadi 0,29 $\mathrm{kW}$.
3. Dengan peningkatan penyerapan kalor maka kerusakan pada coil dapat dieliminasi karena suhu kerja jauh dari suhu lebur tembaga. Sehingga tidak terjadi kebocoran air tungku induksi yang di akibatkan retaknya coil karena mendapat konduksi kalor yang berlebih dari material yang lebur pada proses induksi.

4. Dengan peningkatan penyerapan kalor, material alumunium atau molten dapat dilebur dengan baik karena proses penginduksian logam berjalan sempurna. Dapat mengurangi material molten yang menggumpal dan menepel menutupi dinding furnace yang dapat menyebabkan kerusakan lapisan dinding furnace.

\section{DAFTAR PUSTAKA}

Nunes, Rafael (2004). Metals HandBook volume 15-CASTING. Ebook.

Yunus A Cengel (2002). Heat Transfer A Pratical Approach. University Of Nevada, Reno, Mc. Graw - Hill : Erlangga.

UNEP (2005). Pedoman Efisiensi Energy untuk Industri di Asia, www.energyefficiencyasia.org.

Komarudin, Ir.MT (2012). Perpindahan Panas Dasar. Ebook.

Nasirudin (2012). Optimasi Pengujian pompa seri dan pararel. Poltek Padang. Ebook.

The McGraw-Hill Companies (2014). Properties Of Waters. Ebook. 